\title{
A Review on Basic Concepts and Important Standards of Power Quality in Power System
}

\author{
M. Ramachandran \\ Department of EEE \\ Renganayagi Varatharaj \\ College of Engineering, \\ Sivakasi, India
}

\author{
A. Mariya Chithra Mary \\ M. Muthukumaran \\ J. Ganesan \\ Department of EEE \\ Sree Sowdambika College of \\ Engineering \\ Aruppukottai, India \\ D. Edison Selvaraj \\ Department of EEE \\ Panimalar Engineering College, \\ Chennai, India
}

\author{
A. Krishnaveni \\ Department of ECE \\ P.S.R College of Engineering, \\ Sivakasi, India
}

\begin{abstract}
This paper deals with the basic of Power quality in power system. In addition basic definition and important concepts was discussed in simple way. This paper also covers the important power quality standards. In addition IEEE, IEC, SEMI and UIE Power quality standards are listed. This paper would be helpful for the UG and PG students to study about the basics of Power quality in electrical engineering.
\end{abstract}

Keywords: Transients, Harmonics, Overvoltage, Voltage flickers, PQ standards

\section{INTRODUCTION}

Power quality determines the fitness of electric power to consumer devices. Synchronization of the voltage frequency and phase allows electrical systems to function in their intended manner without significant loss of performance or life [1]. The term was used to describe electric power that drives an electrical load and the load's ability to function properly. Without the proper power, an electrical device (or load) may malfunction, fail prematurely or not operate at all [2]. There are many ways in which electric power can be of poor quality and many more causes of such poor quality power.

The quality of electrical power depends upon the following factor

- Continuity of service

- Variation in voltage magnitude

- Transient voltages and currents

- Harmonic content in the waveforms

\section{BASIC DEFINITION IN POWER QUALITY}

\subsection{Power Quality}

The term electric power quality broadly refers to maintaining a near sinusoidal power distribution bus voltage at rated magnitude and frequency. Other definition of power quality refers to the delivery of high grade of electric service maintaining a sinusoidal load, bus voltage and current at stipulated magnitude and frequency.

\subsection{Custom power devices:}

The technology of the application of power electronics to power distribution system for the benefit of a customer group of customers is called custom power [12]. The device used for this purpose is called custom power devices.

Example of custom power devices are DSTATCOM, DVR and UPQC.

\subsection{Brownout}

Brownout by definition is low voltage for an extended period of time (greater than half a cycle) in which the magnitude of the voltage is reduced [3].

\subsection{DC offset}

The presence of a dc voltage or current in an ac power system is termed DC offset. This can occur as the result of a geomagnetic disturbance or asymmetry of electronic power converters.

\subsection{Inter harmonics}

Voltage or currents having frequency components that not integer multiples of the frequency at which the supply system is designed to operate (example: 50 or $60 \mathrm{~Hz} 0$ ) are called inter harmonics [4]. They can appear as discrete frequencies or as a wideband spectrum. Inter harmonics can be found in networks of all voltage classes.

\subsection{Voltage flickers}

Voltage flickers is rapidly occurring voltage sags caused by sudden and large increases in load current. Voltage flicker is most commonly caused by rapidly varying loads that require a 
large amount of reactive power such as arc furnaces, electric welders, rock crushers, sawmills, wood chippers, metal shredders and amusement rides [11]. It can cause visible flickers in lights and cause other processes to shut down or malfunction.

\subsection{Harmonics}

Harmonics is a sinusoidal component of a periodic wave or quantity having a frequency that is an integral multiple of the fundamental power frequency. The equation representing a harmonic frequency is given by:

$$
\mathrm{fh}=\mathrm{f} 1 * \mathrm{~h}
$$

Where $\mathrm{f} 1$ is the fundamental frequency and $\mathrm{h}$ is the harmonic order.

\subsection{Voltage and Current distortion}

Voltage distortion is any deviation from the nominal sine waveform of the line voltage. Current distortion is any deviation from the nominal sine waveform of the $\mathrm{AC}$ line current [5].

\subsection{Oscillatory transients over voltages}

Switching operations within the distribution network are a major cause of oscillatory transients over voltages. Such operations include

- Switching of utility capacitors banks

- Switching of circuit breakers to clear network fault

- Switching of distribution feeders to rearrange the networks for maintenance or construction.

\subsection{Waveform distortion}

It is the deviation from an ideal sine wave of power frequency principally characterized by the spectral content of the deviation. Harmonics is one of the causes of many types of waveform distortion.

\subsection{Sag}

Voltage sag is an event in which the RMS voltage decreases between 0.1 and 0.9 per unit at the power frequency. It lasts for durations of 0.5 cycles to $1 \mathrm{~min}$.

\subsection{Swell}

Swell is an event in which the RMS voltage increases between 1.1 and 1.8 per unit at the power frequency. It lasts for durations of 0.5 cycles to $1 \mathrm{~min}$.

\subsection{Impulsive transients}

An impulsive transient is a sudden, non-power frequency change in the steady state condition of the voltage and/or current waveforms that is essentially in one direction, either positive or negative, with respect to those waveforms. The most common cause of this type of transient is lightning.

\section{BASIC CONCEPTS IN POWER QUALITY}

\subsection{Most common power quality problem}

Voltage sags are considered the most common power quality problem. These can be caused by the utility or by customer loads. These sags will be from 3 to 30 cycles and can be single or three phase [6]. Depending on the design of the distribution systems, a ground fault on 1 phase can cause a simultaneous swell on another phase.

\subsection{Specifications for good power quality of power}

The variation of electrical quality should be within guaranteed tolerance limit. The wave should be a pure sine wave within allowable limits for distortion.

Voltage should be balanced in all 3 phases.

Supply should be reliable.

The earthing system should serve its purpose properly.

\subsection{Power quality important}

Power quality is an increasingly important issue for all businesses. Problems with powering and grounding can cause data and processing errors that affect production, damaged product and service quality [10].

\subsection{Causes of sags}

Voltage sags are usually associated with system faults but can also be caused by the switching of heavy loads. Voltage sags are caused by motor starting, for example, an induction motor will draw six to ten times its full load current. This lagging current causes a voltage drop across the impedance of the system.

\subsection{Components of waveform distortion}

- DC offset

- Notches

- Flickers

- Harmonics

- Noises

- Inter harmonics

\subsection{Classifications of power quality events in short duration events}

- Sag

- Swell

- Interruption

\subsection{Types of power quality solutions available on the market today}

There are hundreds of manufacturers making thousands of different power quality solutions today. The categories of these solutions are

- Utility based solutions for the substations level.

- User based solution for whole facility protection.

- User load level solutions for specific loads.

\subsection{Power quality problems can be detected by following method \\ - A Piece of equipment misoperates at the same time of day. \\ - Circuit breakers trip without being overloaded. \\ - Equipment fails during a thunderstorm. \\ - Automated systems stop for no apparent reason.}

\subsection{Various power quality issues}

- Poor load power factor 
- Harmonics contents in loads

- Notching in load voltages

- Unbalanced loads

- Supply voltage distortion

- Voltage sags/swell

- Voltage flicker

\subsection{Effects of brownout}

- Temporary low line voltage.

- Shutdowns.

- Loss of microprocessor memory.

- Loss of control.

- Overheating of motors- insulation breakdown.

- Protective device tripping.

- Speed variation

- Reduced motor torque, which can lead to stalling [7].

\subsection{Adverse effects of low power factor}

- Increased line losses $\mathrm{I}^{2} \mathrm{R}$

- Wasted generation capacity (KVA)

-Wasted distribution/transformer/capacity (KVA)

- Wasted system capacity (KVA)

- Reduced system efficiency (KW)

- Increased maximum demand (KVA) and related charges.

- Possible power factor charges.

\subsection{Different types of sag mitigation devices}

Dynamic Voltage Restorer (DVR)

Active series compensators (Transformer less series injection) Solid State (static) Transfer switches (SSTS)

\subsection{Important role of a DVR}

The basic idea of a DVR is to inject a controlled voltage generated by a forced commuted converter in series to the bus voltage by means of an injecting transformer [8].

\subsection{Harmonics effects on devices and loads}

- Insulation stress (voltage effect)

- Thermal stress (current effect)

- Load ruptures (abnormal operation)

\subsection{Various causes of over voltages}

- Atmospheric discharges, i.e, lightning.

- Switching operations in the public grid and low-voltage mains.

- Electrostatic Discharges.

- Ferro resonance

\section{IMPORTANT STANDARDS OF POWER QUALITY}

The most universally accepted standards for power quality are IEC and IEEE standard. Both standards adopt some of the other organization standards [9]. For example IEEE adopts some of ANSI standards as IEEE standards for some specific issues. The following Table 1 shows the important power quality standards
Table 1 Important power quality standards

\begin{tabular}{|l|l|l|}
\hline $\begin{array}{c}\text { S. } \\
\text { No. }\end{array}$ & Abbreviation & \multicolumn{1}{c|}{ The standard name } \\
\hline 1 & IEEE & $\begin{array}{l}\text { Institute of Electrical and } \\
\text { Electronics Engineer }\end{array}$ \\
\hline 2 & IEC & $\begin{array}{l}\text { International Electro technical } \\
\text { Communication }\end{array}$ \\
\hline 3 & CENELEC & $\begin{array}{l}\text { European committee for Electro } \\
\text { technical Standardization }\end{array}$ \\
\hline 4 & ANSI & $\begin{array}{l}\text { American National Standards } \\
\text { Institute }\end{array}$ \\
\hline 5 & NER & National Electricity Regulator \\
\hline 6 & SEMI & $\begin{array}{l}\text { Semiconductor Equipment and } \\
\text { Material International }\end{array}$ \\
\hline 7 & UIE & $\begin{array}{l}\text { International Union for Electricity } \\
\text { Applications }\end{array}$ \\
\hline
\end{tabular}

\subsection{IEC Standards}

The following table 2 shows the Some IEC standards for power quality events

Table 2 Some IEC standards for power quality events

\begin{tabular}{|l|l|}
\hline $\begin{array}{l}\text { IEC 61000 2-5:1995[2], IEC } \\
\text { 61000 2-1:1990[3], IEEE } \\
1159: 1995[4]\end{array}$ & $\begin{array}{l}\text { Characterization of power } \\
\text { quality events }\end{array}$ \\
\hline $\begin{array}{l}\text { IEC 61000 2-1:1990[3], } \\
\text { IEEE 1159:1995[4], } \\
\text { IEC816:1984[6] }\end{array}$ & Transients \\
\hline $\begin{array}{l}\text { IEC 61000 2-1:1990[3], } \\
\text { IEEE 1159[4], }\end{array}$ & Voltage sag/swell \\
\hline $\begin{array}{l}\text { IEC 61000 2-1:1990 [3], } \\
\text { IEEE 1159:1995[4] }\end{array}$ & Interruptions \\
\hline $\begin{array}{l}\text { IEC 61000 2-1: 1990[3]: } \\
\text { IEEE 519:1992[7], } \\
\text { IEC61000 4-7: 1991[8] }\end{array}$ & Harmonics \\
\hline IEC 61000 4-15: 1997[9] & Voltage flicker \\
\hline
\end{tabular}

\subsection{IEEE Power Quality Standards}

- IEEE Std 141-1993, IEEE Recommended Practice for Electric power Distribution for Industrial Plants (IEEE Red Book) (ANSI).

- IEEE Std 142-1999, Recommended practice for Grounding of Industrial and Commercial power Systems (IEEE Green Book) (ANSI).

- IEEE Std 241-1990, IEEE Recommended Practice for Electric Power Systems in Commercial Buildings (IEEE Gray book) (ANSI).

- IEEE Std 242-1986, IEEE Recommended Practice for Protraction and Coordination of Industrial and Power Systems (IEEE Buff Book)(ANSI).

- IEEE Std 399-1990, IEEE Recommended Practice for Industrial and Commercial Power Systems Analysis (IEEE Brown Book) (ANSI).

- IEEE Std 446-1987, IEEE Recommended Practice for Emergency and Standby power Systems for Industrial and Commercial Application (IEEE Orange Book) (ANSI). 
- IEEE Std 487-1992, IEEE Recommended Practice for the Protection of Wire Line Communications Facilities Electric Power Stations.

- IEEE Std 493-1990, IEEE Recommended Practice for the Design of Reliable Industrial and commercial power Systems (IEEE Gold Book) (ANSI).

- IEEE Std 518-1982, IEEE Guide for the Installation of Electrical Equipment to Minimize Noise Inputs to Controllers from External Sources (Reaff 1990) (ANSI).

- IEEE Std 519-1992, IEEE Recommended Practice and Requirement for Harmonics Control in Electric Power Systems (ANSI).

- IEEE P519A, Guide for Applying Harmonics Limits on Power Systems.

- IEEE Std 602-1986, IEEE Recommended Practice for Electric Systems in Health Care (ANSI).

- IEEE Std 739-1995, IEEE Std 739-1995 IEEE Recommended Practice for Energy Management In Industrial And Commercial Facilities (The Bronze Book) Systems (ANSI).

- IEEE Std 929-2000, IEEE Recommended Practice for Utility Interface Photovoltaic (PV) Systems (ANSI).

- IEEE Std 1001-1988, IEEE Guide for Interfacing Dispersed Storage and Generation Facilities with Electric Utility Systems (ANSI).

- IEEE Std 1035-1989, IEEE Recommended Practice: Test Procedure for Utility Interconnected Static Converters (ANSI).

- IEEE Std 1050-1989, IEEE Guide for Instrumentation and Control Equipment Grounding in Generating Station (ANSI).

- IEEE Std 1100-1992, IEEE Recommended Practice for Powering and Grounding Sensitive Electronic Equipment (Emerald Book) (ANSI).

- IEEE Std 1159-1995, IEEE Recommended Practice for Monitoring Electrical Power Quality.

- IEEE Std 1159.1-2003, IEEE Guide for Recorder and Data Acquisition Requirements for characterization of Power Quality Events.

- IEEE Std 1159.2-2003, IEEE Power Quality Event Characterization Status Under Preparation.

- IEEE Std 1159.3-2003, IEEE Recommended Practice for the transfer of Power quality data.

- IEEE Std 1250-1995, IEEE Guide for Service to Equipment Sensitive to Momentary Voltage Disturbance (ANSI).

- IEEE P1346-1998, Recommended Practice or Evaluating Electric Power Systems Compatibility with Electronic Process Equipment.

- IEEE P1433, Power Quality Definition Status:

- IEEE P1453, Voltage Flicker Status:

- IEEE Std C57.110-1986, IEEE Recommended Practice for Establishing Transformer Capability when Supplying Non sinusoidal Load Currents (ANSI).

- IEEE Std C62.41-1991, IEEE Recommended Practice on Surge Voltage in Low Voltage AC Power Circuits (ANSI).
- IEEE Distribution, Power and Regulating Transformers Standards Collection, 1995 Edition (C57) (ANSI).

- IEEE Surge Protection Standards Collection, 1995 Edition (C62) (ANSI).

\section{3 IEC Power Quality Standards}

IEC 61000 Series, Electromagnetic Compatibility (EMC) defines for the following:

Part 1: Definition and Methodology 61000-1-X: Dealing with fundamental definition, etc.

Part 2: Environment 61000-2-X, deals with the characteristics of the environment will be supplied, and its compatibility levels.

Part 3: Limits 61000-3-X, define the permissible emission that can be generated by the equipment connected.

Part 4: Tests and measurements 61000-4-X, Testing and measurement techniques provide detailed guidelines for measurement equipment.

Part 5: Installation and mitigation 61000-5-X, provide guidelines for cabling of electrical and electronics systems, etc. They also describe protection concepts from high-altitude nuclear explosions.

Part 6: Generic immunity and emission 61000-6-X, defining immunity and emission levels required for equipment in general categories or for specific types of equipment.

\subsection{SEMI Power Quality Standards}

- SEMI F47-0200, Specifications for Semiconductor Processing Equipment Voltage Sag Immunity.

- SEMI F42-0600, Test Method for Semiconductor Processing Equipment Voltage Sag Immunity.

\subsection{UIE Power Quality Standards}

- UIE-DWG, Guide to Quality of Electrical Supply for Industrial Installation, Part 1: General Introduction to Electromagnetic Compatibility (EMC).

- UIE-DWG, Guide to Quality of Electrical Supply for Industrial Installations, Part 2: Voltage Dips and Short Interruption.

- UIE-DWG, Guide to quality of Electrical Supply for Industrial Installations, Part 3: Voltage Distortion

- UIE-DWG, Guide to Quality of Electrical Supply for Industrial Installation Part 4: Voltage Unbalance.

- UIE-DWG, Guide to Quality of Electrical Supply for Industrial Installation Part 5: Flicker.

\section{CONCLUSION}

This paper shows the basic concepts of power quality in power system. A special attention was also given to the important of power quality standards. It was the part of Power Quality subject. This paper would give a special knowledge for the UG students to study some fundamentals of power quality.

\section{REFERENCES}

[1] https://en.wikipedia.org/wiki/Power_quality 
[2] Arindam Ghosh Power Qulaity enhancement using custom power devices, kuuwer academic publishers, 2002.

[3] G.T.Heydt Electric Power Quality, Stars in acircle publications, 1994(2nd edition)

[4] Power Quality-R.C.Duggan

[5] Power system harmonics-A.J.Arrillga

[6] Power System Harmonics - November 21, 2003 by Jos Arrillaga (Author), Neville R. Watson (Author)

[7] Basic Electrical Engineering, M.L.Anwani, Dhanpat Rai \& Co.

[8] Electrical Machines -1 J. Gnanavadivel et. Al, Anuradha Publications.

[9] Testing commissioning Operation and maintenance of electrical equipment S.rao, Khanna Publishers

[10] P. Kundur, 'Power System Stability and Control, Tata McGraw Hill, Publications, 1994.

[11] John J. Grainger and W.D. Stevenson Jr., 'Power

System Analysis', McGraw Hill International Book Company, 1994.

[12] I.J. Nagrath and D.P. Kothari, 'Modern Power System Analysis', Tata McGraw-Hill Publishing Company, New Delhi, 1990. 